\title{
PENGARUH KECUKUPAN MODAL TERHADAP PROFITABILITAS BANK SYARIAH YANG TERDAFTAR DI BANK INDONESIA TAHUN 2010
}

\author{
Oleh : \\ Imas Purnamasari \\ (Dosen Program Studi Pendidikan Akuntansi Fakultas Pendidikan Ekonomi \& Bisnis UPI) \\ Edna Ayu Adityani \\ (Alumni Program Studi Pendidikan Akuntansi Fakultas Pendidikan Ekonomi \& Bisnis UPI)
}

\begin{abstract}
Abstrack
The research is investigate the phenomenon of decreasing of earnings in Syariah bank which listed in Indonesia Bank 2010 There are severai factors that can affect the decline in earnings, one of them is the composition of capital adequacy in which the capital has the important role for a bank.Based on the research problem, the writer doing research at syariah bank which listed in Indonesia Bank, the research is to determine the relationship Capital Adequate with Profitability. The method used in this study is the descriptive verification method in which the population in this research is the publication of financial reports of syariah bank listed in Indonesia Bank 2010.To analyze the research data, used simple linier regression analysis obtcined the equation $\widetilde{Y}=1.13+0.01 X$. Based on these equation can be concluded that the capital adequate has $a$ positive influence on profitability, where any increase in capital adequacy will lead to an increase in profitability (ROA). Conversely if the decline in capital adequacy, it will lead to a decrease in profitability (ROA).
\end{abstract}

Keyword: Capital Adequacy (CAR) and Profitability (ROA).

\section{Latar Belakang}

Perbankan di Indonesia semakin diramaikan dengan berdirinya bank-bank umum syariah dan juga unit-unit usaha syariah. Tumbuhnya perbankan syariah tersebut memberikan indikasi bahwa saat ini preferensi masyarakat Indonesia makin mengarah ke arah transaksi-transaksi syariah. Kondisi tersebut menunjukkan bahwa masyarakat mulai sadar akan keberadaan bank syariah sebagai sarana mereka untuk mengelola dana namun tetap berlandaskan pada prinsip syariah yang jelas lebih diridhoi oleh Allah SWT.

Berdasarkan data statistik perbankan syariah Bank Indonesia bulan September 2010, secara kuantitas, pencapaian perbankan syariah terus mengalami peningkatan dalam jumlah bank. Semenjak berdirinya Bank Muamalat Indonesia tahun 1992 sampai 2005 hanya ada tiga Bank Umum Syariah (BUS), 19 Unit Usaha Syariah (UUS), dan 92 Bank Pembiayaan Rakyat Syariah (BPRS) dengan total jumlah kantor baru mencapai 550 unit. Dalam rentang lima tahun (20052010), pertumbuhan perbankan syariah lebih dari dua kali lipat. Jumlah BUS pada tahun 2011, telah mencapai 10 unit dengan 23 UUS. Selain itu, jumlah BPRS telah mencapai 146 unit dan total jumlah kantor syariah sebanyak 1.640 unit. Secara geografis, sebaran jaringan kantor perbankan syariah juga telah menjangkau masyarakat di lebih dari 89 kabupaten/kota di 33 provinsi. Berdasarkan data tersebut, bank syariah juga perlu dinilai kinerja keuangannya. Penilaian kinerja keungan bank dapat dilakukan dengan mengukur tingkat kesehatan bank berdasarkan laporan keuangannya. Tujuannya agar dapat memberi gambaran yang lebih tepat mengenai kondisi saat ini dan mendatang. Penilaian kesehatan bank syariah ini dilakukan berdasarkan Peraturan Bank Indonesia (PBI) No. 9/1/PBL/2007 tentang Sistem Penilaian Tingkat Kesehatan Bank Umum Berdasarkan Prinsip Syariah yang berlaku mulai 24 Januari 2007.

Kasmir (2008:40) berpendapat bahwa penilaian untuk menentukan kondisi suatu bank, biasanya menggunakan berbagai alat ukur. Salah satu alat ukur yang digunakan untuk menentukan kodisi suatu bank dikenal dengan analisis CAMEL. Analisis ini terdiri dari aspek capital, assets, management, earning, dan liquidity. Hasil dari masing-masing aspek ini kemudian menghasilkan 
kondisi suatu bank. Berdasarkan pendapat tersebut, aspek earning atau profitabilitas merupakan salah satu aspek yang dapat menilai kinerja suatu bank apakah sudah baik atau belum. Rasio yang diteliti dalam penelitian adalah rasio profitabilitas dengan indicator ROA. dengan 2010:

Berikut ini adalah gambar perkembangan profitabilitas bank syariah tahun 2005 sampai

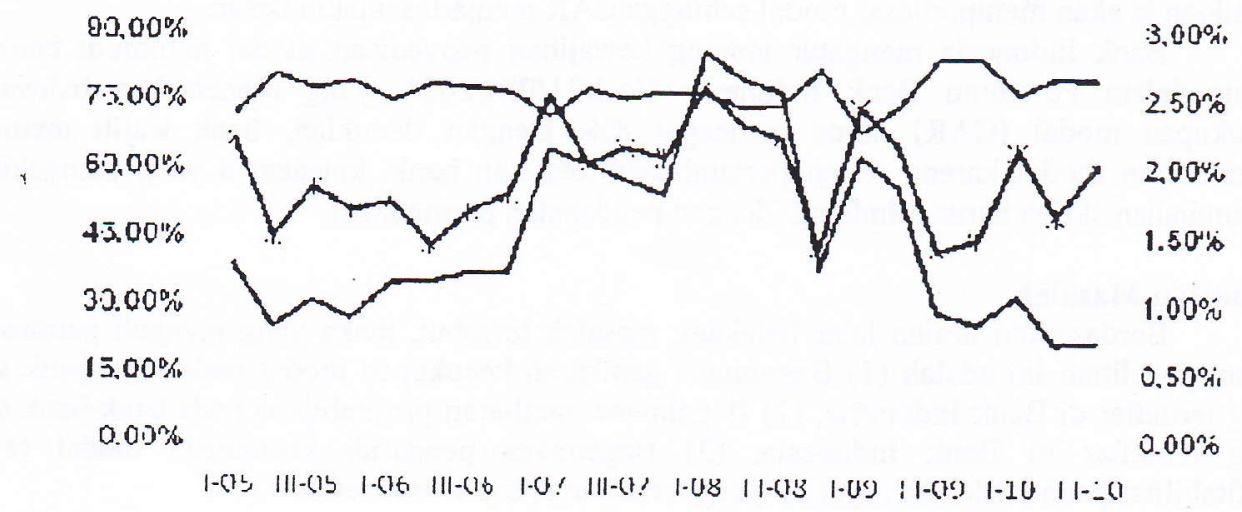

- EOPO iaksis linii —ROE (aksiskini —ROA iakris lianan)

Sumber : Bank Indonesia

Gambar 1 Perkembangan Profitabilitas Perbankan Syariah

Kondisi sektor riil yang kurang kondusif sejak akhir tahun 2008, yang diikuti dengan penurunan kinerja pembiayaan dan mengetatnya persaingan dengan bank konvensional menyebabkan penurunan profitabilitas bank syariah sebagaimana tercermin pada Gambar 1.1 ROA yang menurun dari $2,21 \%$ pada September 2008 menjadi 1,40\% pada September 2009. Dampak kondisi tersebut tercermin pada kenaikan biaya operasional yang mencapai $52,9 \%$, yang memouat rasio BOPO perbankan syariah meningkat dan menyebabkan menurunnya ROE. Pertumbuhan biaya yang tidak diimbangi pertumbuhan pendapatan secara umum menurunkan efisiensi operasional bank syariah, di mana rasio biaya operasional terhadap pendapatan operasional kini mencapai $84,05 \%$ jauh lebih tinggi dibandingkan tahun 2008 sebesar $73,60 \%$. Hal ini perlu diwaspadai karena penurunan efisiensi yang terjadi dibayangi kecenderungan peningkatan jumlah aset bermasalah, jika cenderung bersifat persisten dapat mengakibatkan penurunan kecukupan permodalan atau CAR.

Peningkatan dan penurunan perolehan laba sebelum pajak, menunjukkan terjadinya fluktuasi pada kinerja bank. Peningkatan dan penurunan laba ini disebabkan oleh beberapa hal, salah satunya adalah berasal dari volume kredit yang disalurkan kepada masyarakat. Bila volume kredit dapat disalurkan dengan baik oleh bank, maka tidak akan terjadi penumpukkan laba dan bank memperoleh laba yang lebih besar dari bagi hasil pinjaman kepada masyarakat. Sebagai informasi, rata-rata rasio kecukupan modal atau CAR bank-bank umum syariah pada tahun 2010 masih relatif memadai yaitu pada posisi $14,58 \%$ (www.bi.go.id).

Aspek permodalan bagi perbankan sangatlah penting dalam menentukan operasi bank secara sehat. Agar permodalan bank senantiasa sehat dan didukung oleh quality asset yang sehat pula, otoritas moneter telah menentukan aturan-aturan kesehatan permodalan bank, sehingga bank tidak goyah dalam menghadapi kesulitan-kesulitan yang mungkin timbul. Bank Indonesia dan pengawas perbankan nasional memberikan ketentuan modal minimum atau kecukupan modal yang harus tersedia pada bank umum, bank syariah, dan bank perkreditan rakyat (BPR).

Penilaian permodalan berdasarkan pada kewajiban modal minimum bank sebagaimana ditetapkan dalam Surat Edaran Bank Indonesia Nomor 26/5/BEP tanggal 29 Mei 1993 perihal Kewajiban Penyediaan Modal Minimum (KPMM), yang dinyatakan dalam rasio modal dibagi Aktiva Tertimbang Menurut Resiko (ATMR). Rasio ini diistilahkan dengan Capital Adequaci Ratio (CAR) biasanya dinyatakan dalam persen (\%). Oleh karena itu dengan mengetahui CAR suatu bank, maka dapat diketahui seberapa besar aktiva yang memiliki resiko pada bank tersebut. 
CAR juga merupakan salah satu penentu faktor besarnya volume kredit yang disalurkan kepada masyarakat dan dunia usaha, semakin besar laba yang berasal dari volume kredit maka akan semakin besar pula CAR pada bank tersebut.

Diperkuat oleh pendapat N. Lapoliwa dan Daniel S (2000:137-142) bahwa bila laba usaha setiap tahunnya besar dan tidak semuanya dibagikan kepada pemegang saham, maka akan terjadi penumpukan laba yang ditahan yang semakin besar dari suatu periode ke periode lainnya. Dengan demikian ia akan memperbesar modal sehingga CAR menjadi semakin besar.

Bank Indonesia mengatur tentang kewajiban penyediaan modal minimum bank yang diatur dalam Peraturan Bank Indonesia No.3/21/PBI/2001, yang menetapkan bahwa rasio kecukupan modal (CAR) harus mencapai 8\%. Dengan demikian, bank wajib memelihara ketersediaan modal karena setiap pertambahan kegiatan bank, khususnya yang mengakibatkan pertambahan aktiva harus diimbangi dengan pendapatan permodalan.

\section{Rumusan Masalah}

Berdasarkan uraian latar belakang masalah tersebut, maka yang menjadi permasalahan dalam penelitian ini adalah (1) Bagaimana gambaran kecukupan modal pada bank-bank syariah yang terdaftar di Bank Indonesia, (2) Bagaimana gambaran profitabilitas pada bank-bank syariah yang terdaftar di Bank Indonesia, (3) Bagaimana pengaruh kecukupan modal terhadap profitabilitas pada bank-bank syariah yang terdaftar di Bank Indonesia.

\section{Kerangka Pemikiran}

Penilaian terhadap kinerja suatu bank dapat dilakukan dengan melakukan analisis terhadap laporan keuangnya. Laporan keuangan bank berupa neraca memberikan informasi kepada pihak di luar bank, misalnya bank sentral, masyarakat umum, dan investor, mengenai gambaran posisi keuangannya, yang lebih jauh dapat digunakan pihak eksternal untuk menilai besarnya resiko yang ada pada suatu bank. Laporan laba rugi memberikan gambaran mengenai perkembangan bank yang bersangkutan.

Pengukuran tingkat kesehatan bank harus dilakukan oleh semua bank, baik bank konvensional maupun bank syariah karena terkait dengan kepentingan semua pihak terkait, baik pemilik, pengelola (manajemen) bank, masyarakat pengguna jasa bank, Bank Indonesia selaku otoritas pengawasan bank, dan pihak lainnya. Informasi mengenai kondisi suatu bank dapat digunakan oleh pihak-pihak tersebut untuk mengevaluasi kinerja bank dalam menerapkan prinsip kehati-hatian, kepatuhan terhadap ketentuan-ketentuan yang berlaku dan manajemen resiko. Rasio yang digunakan untuk mengukur efektifitas manajemen berdasarkan hasil pengembalian yang dihasilkan dari pinjaman dan investasi adalah rasio profitabilitas. Indikator yang digunakan untuk mengukur kinerja profitabilitas bank dalam penelitian ini adalah ROA (Return on Assets) yaitu rasio yang menunjukkan kemampuan dari keseluruhan aktiva yang ada dan yang digunakan untuk menghasilkan keuntungan.

Lukman Dendawijaya (2009:119) berpendapat bahwa ROA digunakan untuk mengukur kemampuan manajemen bank dalam memperoleh keuntungan (laba sebelum pajak) yang dihasilkan dari rata-rata total aset bank yang bersangkutan. Semakin besar ROA suatu bank, semakin besar pula tingkat keuntungan yang dicapai bank tersebut dan semakin baik pula posisi bank tersebut dari segi penggunaan aset. Sebagaimana Surat Edaran Bank Indonesia No. 6/23/DPNP, mengemukakan bahwa "rasio-rasio profitabilitas untuk menilai kesehatan bank yaitu Return On Asset (ROA), Return on Equity (ROE), Net Interest Margin (NIM), dan BOPO", diperkuat lagi dengan Peraturan Bank Indonesia (No.6/10/PBI/2004) tentang Sitem Penilaian Tingkat Kesehatan Bank Umum, yang mengemukakan bahwa "penilaian kesehatan perbankan mencakup faktor-faktor permodalan (capital), kualitas aset (asset quality), manajemen (management), profitabilitas (earning), likuiditas (liquidity), dan sensitifitas (sensivity). Modal bank merupakan salah satu faktor yang mempengaruhi profitabilitas bank. semakin besar modal yang diperoleh oleh bank maka akan semakin besar pula kemampuan memperoleh laba yang akan diterima oleh bank. Kecukupan modal merupakan salah satu faktor penentu besarnya volume kredit yang disalurkan kepada masyarakat dan dunia usaha. Taswan (2010:224) berpendapat bahwa tingkat kecukupan modal sangat tergantung dari portofolio asetnya. Semakin besar 
penempatan dana pada aset beresiko tinggi, maka akan semakin rendah rasio kecukupan modal (dengan asumsi tidak ada tambahan modal yang proporsional).

Kecukupan modal merupakan faktor yang penting bagi bank untuk mengembangkan usaha dan inenampung risiko (kerugian). Intensif bank untuk mengambil risiko tinggi atau rendah sangat tergantung dari prospek laba bank. Untuk mengukur tingkat kecukupan modal digunakan rasio kecukupan modal (CAR). Menurut Suliso Sri (2000:27) "Bank Indonesia menetapkan CAR yaitu sebagai kewajiban penyediaan modal minimum yang harus selalu dipertahankan oleh setiap bank sebagai suatu proporsi tertentu dari Aktiva Tertimbang Menurut Resiko (ATMR)". Setiap bank yang beroperasi di Indonesia diwajibkan untuk memelihara Kewajiban Penyediaan Modal Minimum (KPMM) sekurang-kurangnya 8\%. Minimum CAR (Capital Adequacy Ratio) sebesar $8 \%$ ini, dari waktu ke waktu akan disesuaikan dengan kondisi dan perkembangan perbankan yang teijadi, dengan tetap mengacu pada standar internasional yaitu Banking for International Settelman (BSI) yang berpusat di Geneva.

Beberapa penelitan yang pernah dilakukan terdahulu mengenai tingkat profitabilitas dan kecukupan modal antara lain penelitian yang dilakukan oleh M. Sapri Pamulu, Stephen Kajewskim and Martin Betts (2007) menyebutkan bahwa Capital Adequacy Ratio (CAR) berpengaruh positif terhadap tingkat profitabilitas. Penelitian yang dilakukan oleh Yoonhe Tina Chang (2006) menyebutkan bahwa Capital Adequacy Ratio (CAR) tidak berpengaruh negatif terhadap profitabilitas perusahaan dengan Return On Assets (ROA) sebagai indikator profitabilitas.

Berdasarkan paparan kerangka pemikiran dan permasalahan di atas, maka hipotesis dalam penelitian ini dirumuskan sebagai berikut : "Kecukupan modal berpengaruh terhadap profitabilitas bank syariah yang terdaftar di Bank Indonesia tahun 2010".

\section{Metodologi Penelitian}

Penelitian ini menggunakan metode deskriptif verifikatif. Menurut Moh. Nazir (2005:54), "metode deskriptif adalah suatu metode dalam meneliti status kelompok manusia, suatu objek, suatu kondisi, suatu sistem pemikiran atau suatu kelas peristiwa". Sedangkan metode verifikatif menurut Iqbal Hasan (2008:11), "yaitu menguji kebenaran sesuatu (pengetahuan) dalam bidang yang telah ada dan digunakan untuk menguji hipotesis yang menggunakan perhitungan statistik".

Adapun operasionalisasi variabelnya digambarkan sebagai berikut:

Tabel 1 Operasionalisasi Variabel

\begin{tabular}{|l|c|l|}
\hline \multicolumn{1}{|c|}{ Variabel } & Indikator & Keterangan \\
\hline $\begin{array}{l}\text { Kecukupan Modal } \\
\text { (Variabel X) }\end{array}$ & $C A R=\frac{\text { Modal Sendíri }}{A T M R} \times 100 \%$ & Rasio \\
\hline $\begin{array}{l}\text { Profitabilitas } \\
\text { (Variabel Y) }\end{array}$ & ROA $=\frac{\text { Laba sebelum pajak }}{\text { total aset }} \times 100 \%$ & Rasio \\
\hline
\end{tabular}

Dalam penelitian ini jenis data yang digunalan adalah data sekunder. Data sekunder yang dijadikan sumber data berupa laporan keuangan bank-bank syariah yang terdaftar di Bank Indonesia, sumber data diperoleh dengan cara mengunduh laporan keuangan melalu situs www.bi.go.id dan melihat bank yang terdaftar di Bank Indonesia tahun 2010. Terdapat 11 bank syariah yang terdaftar di Bank Indonesia. Pengujian dan Analisis data dilakukan dengan analisis deskriptif dan pengujian hipotesis menggunakan analisis regresi.

Deskripsi Hasil Penelitian

Kecukupan Modal Bank Syariah tabel berikut:

Setelah dilakukan perhitungan Nilai rata-rata CAR dari seluruh bank dapat dilihat pada 
Tabel 4. Nilai Rata-rata Kecukuapan Modal (CAR) Bank Syariah yang terdaftar di Bank Indonesia tahun 2010

\begin{tabular}{|c|l|r|r|}
\hline No & \multicolumn{1}{|c|}{ Nama Bank } & \multicolumn{1}{c|}{ CAR $(\%)$} & Keierangan \\
\hline 1 & PT BANK BNI SYARIAH & 27,03 & Sehat \\
\hline 2 & PT BANK MUAMALAT INDONESIA & 12,94 & Sehat \\
\hline 3 & PT BANK SY ARIAH MANDIRI & 10,41 & Sehat \\
\hline 4 & PT BANK SY ARIAH MEGA INDONESIA & 13,07 & Sehat \\
\hline 5 & PT BANK BCA SYARIAH & 76,56 & Sehat \\
\hline 6 & PT BANK BRI SYARIAH & 21,51 & Sehat \\
\hline 7 & PT BANK JABAR BANTEN SYARIAH & 31,29 & Sehat \\
\hline 8 & PT BANK PANIN SYARIAH & 54,95 & Sehat \\
\hline 9 & PT BANK SYARIAH BUKOPIN & 10,99 & Sehat \\
\hline 10 & PT BANK VICTORIA SYARIAH & 196,88 & Sehat \\
\hline 11 & PT BANK MAYBANK SYARIAH INDONESIA & 124,43 & Sehat \\
\hline & Min & 10,41 & Sehat \\
\hline & Max & 196,88 & Sehat \\
\hline & Rata-rata & 52,73 & Sehat \\
\hline
\end{tabular}

Sumber: (data diolah kembali)

Berdasarkan data di atas PT Bank Muamalat Indonesia memperoleh rata-rata CAR terendah yaitu sebesar $11,29 \%$. Walaupun PT Bank Syariah Mandiri memperoleh nilai CAR terendah dibandingkan bank syariah lain yang terdaftar di Bank Indonesia tetapi nilai rata-rata CAR yang diperoleh lebih dari batas minimum yang ditetapkan Bank Indonesia. Sedangkan hasil perhitungan nilai rata-rata CAR tertinggi dicapai PT Bank Victoria Syariah sebesar 196,88\%. Besarnya nilai CAR yang dimiliki bank tergantung dari modal dan aktiva tetap menurut risiko (ATMR) yang dimiliki bank bersangkutan.

\section{Profitabilitas Bank Syariah}

Profitabilitas merupakan alat yang digunakan untuk mengukur tingkat efesiensi usaha dan tingkat profitabilitas yang dicapai bank. Profitabilitas yang digunakan dalam penelitian ini berdasarkan Return On Assets (ROA). Setelah dilakukan perhitungan diperoleh nilai rata-rata ROA dari masing-masing bank. Nilai rata-rata ROA dapat dilihat pada tabel berikut : 
Tabel 5 Rata-rata Profitabilitas (ROA) Bank Syariah yang terdaftar di Bank Indonesia tahun 2010

\begin{tabular}{|c|l|r|c|}
\hline No & \multicolumn{1}{|c|}{ Nama Bank } & \multicolumn{1}{|c|}{$\begin{array}{c}\text { ROA } \\
(\%)\end{array}$} & Keterangan \\
\hline 1 & PT BANK BNI SYARIAH & 0,53 & Kurang Sehat \\
\hline 2 & PT BANK MUAMALAT INDONESIA & 1,04 & Cukup Sehat \\
\hline 3 & PT BANK SYARIAH MANDIRI & 1,70 & Sehat \\
\hline 4 & PT BANK SYARIAH MEGA INDONESIA & 1,94 & Sehat \\
\hline 5 & PT BANK BCA SYARIAH & 8,42 & Sehat \\
\hline 6 & PT BANK BRI SYARIAH & 0,22 & Tidak Sehat \\
\hline 7 & PT BANK JABAR BANTEN SYARIAH & 0,70 & Kurang Sehat \\
\hline 8 & PT BANK PANIN SYARIAH & $(1,88)$ & Tidak Sehat \\
\hline 9 & PT BANK SYARIAH BUKOPIN & 0,69 & Kurang Sehat \\
\hline 10 & PT BANK VICTORIA SYARIAH & 1,17 & Kurang Sehat \\
\hline 11 & PT BANK MAYBANK SYARIAH INDONESIA & 1,60 & Sehat \\
\hline & Min & $(1,88)$ & Tidak Sehat \\
\hline & Max & 8,42 & Sehat \\
\hline & Rata-rata & 1,47 & Cukup Sehat \\
\hline
\end{tabular}

Sumber: (data diolah kembali)

Dari tabel 5 dapat dilihat tahwa nilai rata-rata profitabilitas yang digambarkan oleh ratarata ROA 11 bank syariah yang terdaftar di Bank Indonesia tahun 2010 sebesar 1,47\%. Ini berarti ROA yang dimiliki bank syariah yang terdaftar di Bank Indonesia memiliki kategori cukup sehat. Rata-rata ROA terendah dimiliki oleh PT Bank Panin Syariah yaitu $-1,88 \%$. Hal ini berarti bahwa ROA yang dimiliki bank mempuyai kategori tidak sehat Sementara untuk hasil perhitungan nilai rata-rata ROA tertinggi diperoleh PT Bank BCA Syariah yaitu sebesar $8,42 \%$.

Pengujian Hipotesis Penelitian

Pengujian hipotesis dilakukan untuk mengetahui apakah variabel independen (kecukupan modal) memiliki pengaruh terhadap variabel dependen (profitabilitas). Data yang digunakan adalah data dalam tabel 4 untuk CAR dan tabel 5 untuk ROA, kemudian dari data tersebut akan dilakukan pengujian dengan statistik.

\section{Analisis Regresi Linier Sederhana}

Dalam penelitian ini regresi digunakan untuk mengetahui bagaimana pengaruh kecukupan modal terhadap profitabilitas. Persamaan yang digunakan adalah regresi linier sederhana. Dari hasil perhitungan diperoleh persamaan regresi linier sederhana antara kecukupan modal dengan profitabilitas sebagai berikut:

\section{$\widehat{Y}=1,13+0,01 X$}

Berdasarkan persamaan regresi di atas dapat diketahui bahwa koefisien a sebesar 1,13 yang berarti, jika tidak mempunyai kecukupan modal $(X=0)$ maka bank akan tetap memperoleh laba sebesar 1,13 . Sedangkan koefisien b sebesar 0,01 artinya setiap kenaikan kecukupan modal 1 $(X=1)$, maka akan menaikan profitabilitas sebesar 1,14 . Tanda $(+)$ menyatakan arah hubungan yang searah (positif), dimana setiap kenaikan variabel $X$ akan mengakibatkan kenaikan pula pada variabel $Y$ begitupun sebaliknya, jika terjadi penurunan variabel $X$ maka akan mengakibatkan penurunan pada variabel $Y$. 
Berdasarkan tabel 4 secara umum perolehan CAR bank syariah yang terdaftar di Bank Indonesia dikategorikan sehat dengan perolehan di atas $8 \%$, dengan rata-rata CAR selama tahun 2010 adalah sebesar 52,73\%. Artinya secara keseluruhan bank syariah yang terdaftar di Bank Indonesia telah memenuhi aturan kewajiban penyediaan modal minimum yang telah ditetapkan Bank Indonesia yaitu sebesar $8 \%$. Hal ini sesuai dengan surat keputusan Direksi BI No. 26/20/Kep/Dir dan SE BI No. 26/2/BPPP tanggal 29 Mei 1993. Ketentuan tersebut mengatur bahwa penyediaan modal minimum bank diukur dari persentasi tertentu terhadap Aktiva Tertimbang Menurut Resiko (ATMR) sebesar 8\% dari ATMR. Penentuan Kewajiban penyediaan modal minimum atau CAR pada dasarnya merupakan suatu ukuran modal yang diharapkan dapat menjamin bahwa bank yang beroperasi secara internasional maupun nasional akan beroperasi secara baik atau prudent.

Besarnya nilai CAR tergantung dari modal dan aktiva tertimbang menurut resikonya. Modal ini digunakan untuk mempertahankan kelangsungan operasional bank dan juga untuk menutupi kerugian yang terjadi akibat aktiva produktif yang bermasalah. Tingkat kecukupan modal sangat tergantunga dari asetnya. Semakin besar penempatan dana pada aset beresiko tinggi, maka akan semakin rendah rasio kecukupan modal. Sebaliknya penempatan dana pada aset yang beresiko rendah, maka dapat menaikkan tingkat kecukupan modal.

Berdasarkan data CAR pada tabel 4, CAR bank syariah yang terdaftar di Bank Indonesia dikategorikan sehat, ini berarti bank syariah lebih menekankan kepada aset beresikonya sehingga CAR yang diperoleh bank akan tinggi. Oleh karena itu, bank harus mampu mempertahankan tingkat kesehatannya dengan tetap menjaga prinsip kehaii-hatian dalam menjalankan usahanya.

Berdasarkan tabel 5 dapat dilihat bahwa rata-rata ROA 11 bank syariah yang terdaftar di Bank Indonesia sebesar 1,47\%. Ini artinya ROA yang dimiliki bank syariah yang terdaftar di Bank Indonesia mempunyai kategori cukup sehat. Tetapi jika dilihat pada masing-masing bank terdapat bank syariah uang memiliki ROA dengan kategori tidak sehat yaitu PT Bank BRI Syariah dan PT Bank Panin Syariah; dengan kategori kurang sehat yaitu PT Bank Jabar Banten Syariah, PT Bank Syariah Bukopin, PT Bank Victoria Syariah, dan PT Bank BNI Syariah; dengan kategori cukup sehat yaitu PT Bank. Muamalat Indonesia; dan dengan kategori sehat yaitu PT Bank Syariah Mandiri, PT Bank Syariah Mega Indonesia, PT Bank BCA Syariah, dan PT Bank Maybank Syariah Indonesia.

Bank yang memiliki kategori tidak sehat berarti bank tersebut mengalami masalah dalam profitabilitas sehingga bank tersebut dikategorikan tidak sehat. Dapat dilihat pada tabel 5 , bank yang dikategorikan tidak sehat tersebut memiliki laba sebelum pajak yang rendah, bahkan ada yang mengalami kerugian. Ini berarti bank kurang mampu mengelola aset dan laba sebelum pajak yang diperoleh bank. Dalam teori disebutkan bahwa faktor-faktor yang mempengaruhi profitabilitas diantaranya yaitu jumlah modal, kualitas kredit yang diberikan dan pengembaliannya, perpencaran bunga bank, manajemen pengalokasian dalam aktiva likuid, efesiensi dalam menekan biaya operasi dan non operasi serta mobilisasi dana masyarakat dalam memperoleh sumber dana yang murah. Dan salah satu diantaranya adalah faktor kecukupan modal.

Mengenai bagaimana pengaruh kecukupan modal terhadap profitabilitas tersebut perlu diuji lebih jauh melalui penelitian secara empiris. Hal tersebut dilakukan untuk membuktikan bahwa ada keterkaitan antara kecukupan modal dengan profitabilitas. Untuk itu, dalam penelitian ini dilakukan pengujian atas hipotesis yang telah diajukan pada bab I untuk membuktikan secara ilmiah mengenai pengaruh antara kecukupan modal dan profitabilitas.

Besar kecilnya profitabilitas bank tergantung pula dari modal yang dimiliki bank. Oleh karena itu, bank harus dapat mengelola modalnya dengan baik. Kecukupan modal yang tinggi merupakan harapan setiap bank. Dengan terpenuhinya modal maka menunjukkan bank tersebut mampu tumbuh dan berkembang dengan kekuatan sendiri yaitu dari sisa laba bank. Bank dengan permodalan yang kuat akan lebih memiliki peluang dalam memperoleh laba yang besar, karena dengan jumlah modal yang besar bank mampu untuk melakukan ekspansi pasar dibandingkan dengan bank yang memiliki jumlah modal relatif kecil. Dengan tersedianya modal, maka bank juga akan lebih leluasa dalam melakukan aktivitasnya.

Dengan hipotesis yang penulis ajukan yaitu pengaruh kecukupan modal terhadap profitabilitas pada bank syariah yang terdaftar di Bank Indonesia pada tahun 2010. Hipotesis dibuktikan kebenarannya dari hasil pengujian hipotesis bahwa kecukupan modal berpengaruh 
positif terhadap profitabilitas bank syariah yang terdaftar di Bank Indonesia pada tahun 2010. Bila kecukupan modal suatu bank besar maka profitablitas bank tersebut akan besar, dan sebaliknya bila kecukupan modal suatu bank kecil maka profitabilitas bank tersebut akan kecil.

Hasil penelitian ini sejalan dengan penelitian sebelumnya yang dilakukan oleh Aya Sofia. (2010) dengan judul Pengaruh Kecukupan Modal terhadap Profitabilitas Bank yang terdaftar di Bursa Efek Indonesia, dimana hasil akhirnya memberikan kesimpulan bahwa kecukupan modal berpengaruh positif terhadap prufitabilitas.

Hal ini berarti bahwa hipotesis yang penulis ajukan yaitu pengaruh kecukupan modal terhadap profitabilitas bank syariah yang terdaftar di Bank Indonesia tahun 2010, dibuktikan kebenarannya dari hasil pengujian hipotesis bahwa kecukupan modal berpengaruh positif terhadap profitabilitas bank syariah yang terdaftar di Bank Indonesia tahun 2010.

\section{Simpulan}

Berdasarkan hasil penelitian dan pembahasan pada BAB IV, maka penulis dapat menyimpulkan bahwa :

1. Kecukupan modal pada bank syariah yang terdaftar di Bank Indonesia tahun 2010 berada dalam kondisi yang berfluktuasi dan dikategorikan dalam keadaan sehat.

2. Profitabilitas yang dimiliki oleh bank syariah yang terdaftar di Bank Indonesia tahun 2010 berada pada kondisi yang fluktuatif dan dikategorikan cukup sehat,. kategori cukup sehat dikarenakan terdapat bank syariah yang belum mampu mengelola labanya dengan baik, sehingga terjadi kerugian.

3. Setelah dilakukan analisa regresi linier sederhana didapatkan persamaan yang berarti bahwa kecukupan modal mempunyai pengaruh yang positif terhadap profitabilitas, dimana setiap kenaikan kecukupan modal akan mengakibatkan kenaikan pada profitabilitas.

Saran

Sebagai tindak lanjut atas simpulan penelitian di atas, maka penulis mengajukan saran antara lain sebagai berikut:

1. Bank Syariah sudah mampu memenuhi kewajiban penyediaan modal minimum yang ditetapkan oleh Bank Indoensia dan diharapkan mampu untuk mempertahankan rasio tersebut dengan pengelolaan modal yang lebih baik.. Pengelolaan modal dapat dilakukan dengan menyusun rencana keuangan secara menyeluruh, menentukan modal bank yang optimal atau memadai, dan pemenuhan modal dari internal bank.

2. Besarnya profitabilitas yang diukur oleh ROA pada bank syariah yang terdaftar di Bank Indonesia yang memiliki kategori sehat sebaiknya dipertahankan dengan menjaga total aset dan laba sebelum pajaknya. Pertumbuhan aset dapat ditingkatkan melalui pengalokasian dana dalam bentuk penyaluran kredit, investasi portofolio, penanaman dana dalam bentuk aktiva tetap, penanaman dana pada aktiva produktif (surat berharga, kredit yang diberikan, penyertaan modal, penempatan dana pada bank lain), dan penanaman dana pada aktiva non produktif (kas, giro BI, dan warkat).

3. Bagi peneliti selanjutnya yang merasa tertarik dapat meneliti faktor-faktor lain yang juga mempengaruhi profitabilitas bank tersebut, misalnya kualitas aktiva produktif, jumlah aktiva produkif, efisiensi, bunga Sertifikat Bank Indonesia (SBI), dan nilai tukar. Oleh karena itu, untuk penelitian selanjutnya faktor-faktor tersebut diteliti agar didapat kesimpulan yang lebih akurat dan untuk dijadikan acuan prediksi yang wajar bagi bank.

Daftar Pustaka

Abdul Ghofur Anshori. (2008). Penerapan Prinsip Syariah dalam Lembaga Keuangan, Lembaga Pembiayaan, dan Perusahaan Pembiayaan. Yogyakarta: Pustaka Pelajar.

Adiwarman Karim. (2004). Bank Islam Analisis Fiqih dan Keuangan. Jakarta: Raja Grafindo Persada.

Aya Sofia. (2010). Pengaruh Kecukupan Modal terhadap Profitabilitas Bank yang terdaftar di Bursa Efek Indonesia. Skripsi. Bandung: UPI.

Chang, T. Yoonhe. (2006). Role of Non Performing Loans (NPL) and Capital Adequacy in Banking Structure and Competition. Jurnal. 
Dahlan Siamat. (2005). Manajemen Lembaga Keuangan. Jakarta: Lembaga penerbit Fakultas Ekonomi Universitas Indonesia.

Dwi Nur Kusumastuti. (2010). Pengaruh Capital Adequacy Ratio (CAR), Financing To Deposit Ratio (FDR) dan Non Performing Financing (NPF) terhadap Tingkat Profitabilitas PT. Bank Syariah Mandiri, Tbk. Skripsi. Bandung: UNPAD

Fitria Astuti. (2008). Pengaruh Tingkat Kecukupan Modal (CAR) dan Likuiditas (LDR) terhadap Tingkat Profitabilitas Bank (Survei pada Bank-bank yang Listing di BEJ). Skripsi. Bandung: Widyatama.

Iqbal Hasan. (2008). Analisis Data Penelitian dengan Statistik. Jakarta: PT bumi Aksara.

Kasmir. (2008). Bank dan Lembaga Keuangan Lainnya Edisi Revisi Delapan. Jakarta: Raja Grafindo Persada.

Kieso, Donald E dan Weygandt, Jerry J. (2008). Intermediate Accounting. Asia: McGraw-Hill Education

Ktut Silvanita. (2009). Bank dan Lembaga Keuangan Lain. Jakarta: Erlangga.

Lukman Dendawijaya. (2009). Manajemen Perbankan. Jakarta: Ghalia Indonesia.

M. Sapri Pamulu, Kajeski, Stephen.L, dkk. (2007). Evaluating Financial Ratios in Construction Industry : A Case Study of Indonesian Firms. Jurnal.

Moh. Nazir. (2005). Metode Penelitian. Jakarta: Indonesia.

N. Lapoliwa, dan Daniel. (2000). Akuntansi Perbankan akuntansi transaksi bank dalam valuta rupiah. Jakarta: Institut Bankir Indonesia.

S. Munawir. (1995). Analisa Laporan Keuangan. Yogyakarta: Liberty Yogyakarta.

Sudjana. (1997). Metode Statistika Edisi Ke-6. Bandung: Tarsito.

Sugiyono. (2008). Metode Penelitian Bisnis. Bandung: CV Alfa Beta.

Taswan. (2010). Manajemen Perbankan Konsep, Teknik dan Aplikasi. Yogyakarta: UPP STIM YKPN Yogyakarta.

Teguh Pujdo Mulyono. (2001). Bank Budgeting Profit Planning \& Control Buku Petunjuk Tentang Penyusunan Anggaran Bank Terutama dalam rangka Perencanaan Laba Serta Pengendaliannya. Yogyakarta: BPFE- Yogyakarta.

Zainul Arifin. (2009). Dasar-dasar Manajemen Bank Syariah. Jakarta: Pustaka Alvabet. 